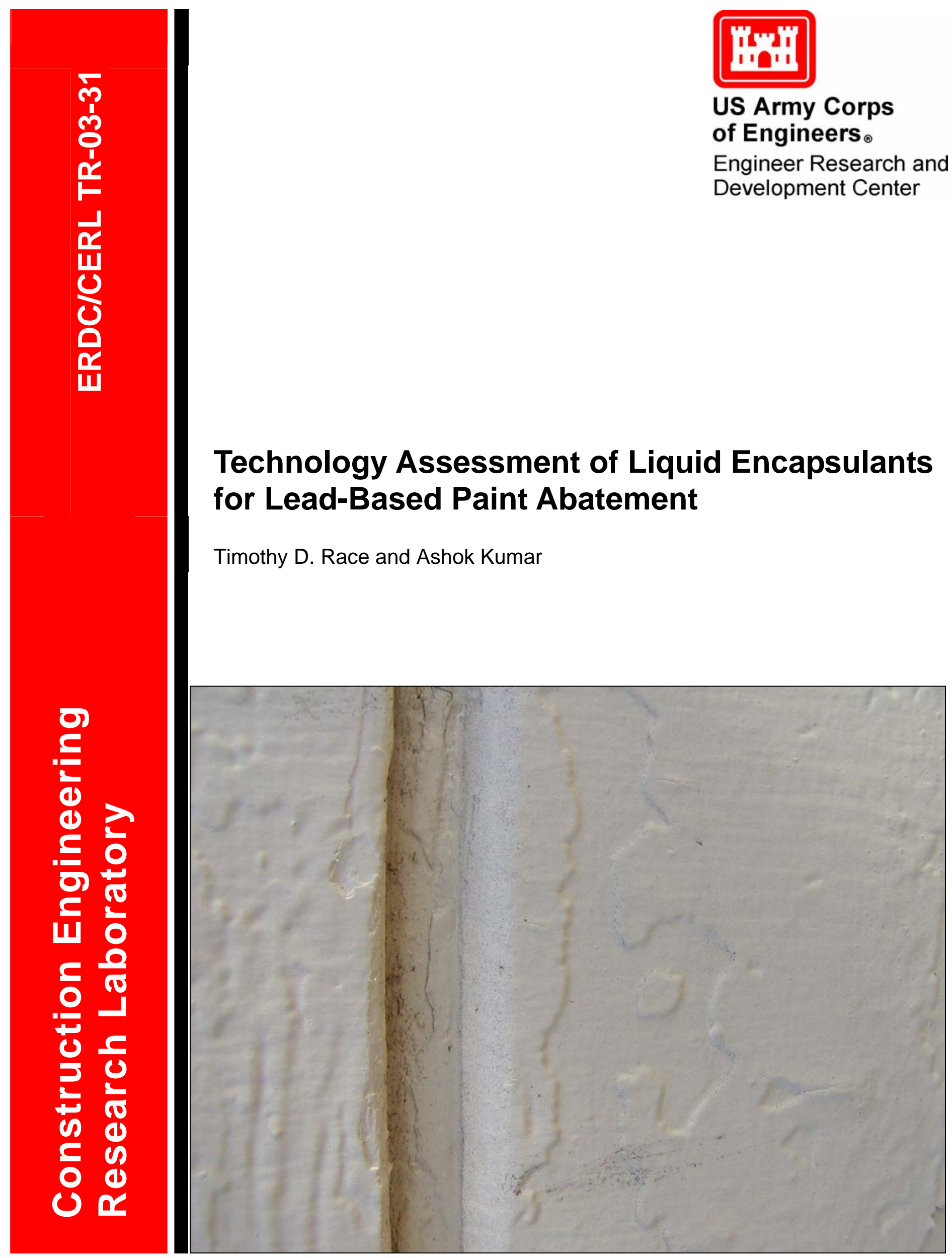





\section{Technology Assessment of Liquid Encapsulants for Lead-Based Paint Abatement}

Timothy D. Race and Ashok Kumar

Construction Engineering Research Laboratory

PO Box 9005

Champaign, IL 61826-9005

Final Report

Approved for public release; distribution is unlimited.

Prepared for U.S. Army Corps of Engineers

Washington, DC 20314-1000

Under $\quad$ Work Unit CF-M B101 
ABSTRACT: An evaluation of lead-based paint maintenance options was conducted based on realistic life-cycle cost assessments of the relative durabilities of encapsulants and conventional paint when employed using the same approaches. A record of field experiences of several military installations with cost and performance of encapsulants versus maintenance painting with standard specification paints was developed.

It was found that, irrespective of initial paint condition, it is generally more cost-effective to control lead hazards by paint stabilization than by encapsulation on interior and dimensionally stable exterior substrates. Only in the case of exterior wood substrates were encapsulants found to be slightly more cost-effective than paint stabilization. However, this small cost advantage does not account for the potential risk of lead hazard control failure, a risk that is not yet well quantified for encapsulants since they are still relatively new to the market. Proper surface preparation is the primary cost driver for both encapsulation and paint stabilization, so for either technology to perform as intended, the surfaces to which they are applied must be properly prepared and all substrate damage must be repaired.

DISCLAIMER: The contents of this report are not to be used for advertising, publication, or promotional purposes. Citation of trade names does not constitute an official endorsement or approval of the use of such commercial products. All product names and trademarks cited are the property of their respective owners. The findings of this report are not to be construed as an official Department of the Army position unless so designated by other authorized documents.

DESTROY THIS REPORT WHEN NO LONGER NEEDED. DO NOT RETURN IT TO THE ORIGINATOR. 


\section{Contents}

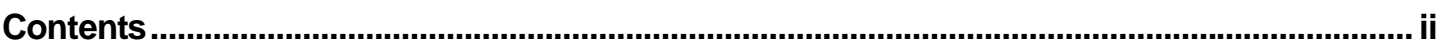

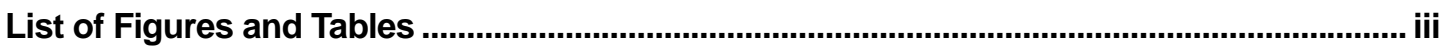

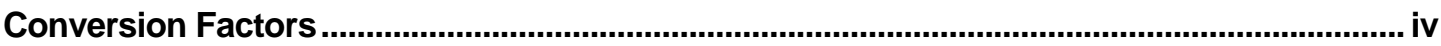

Preface

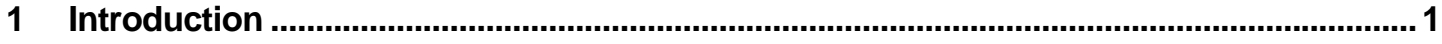

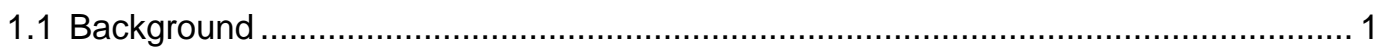

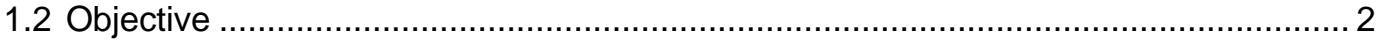

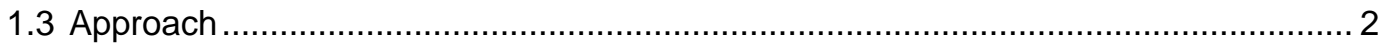

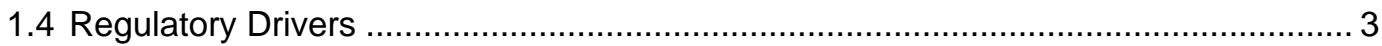

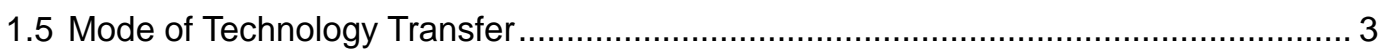

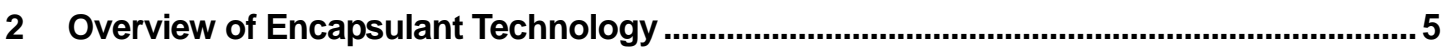

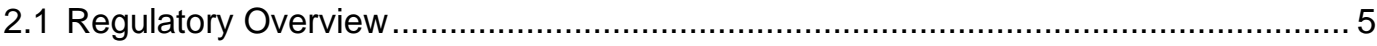

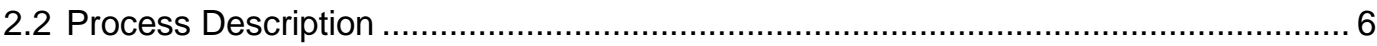

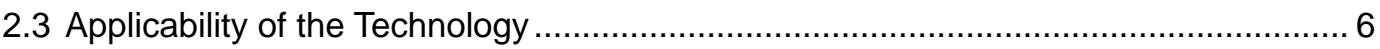

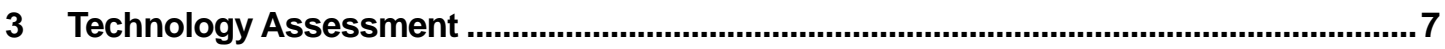

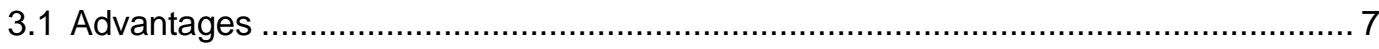

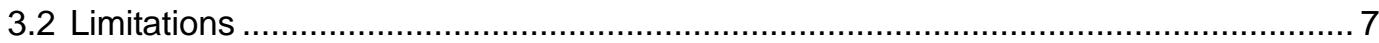

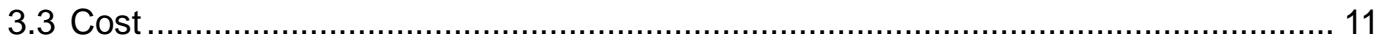

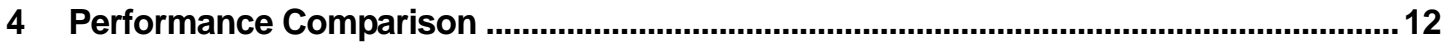

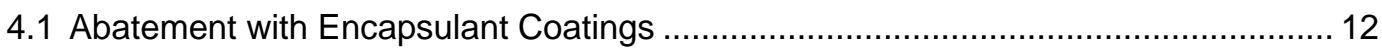

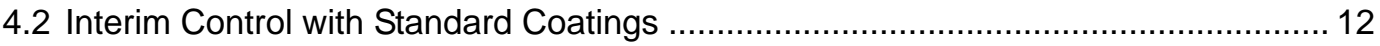

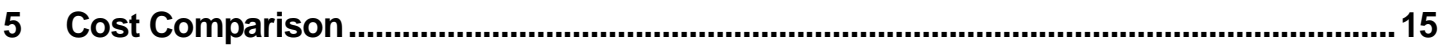

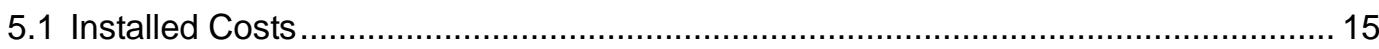

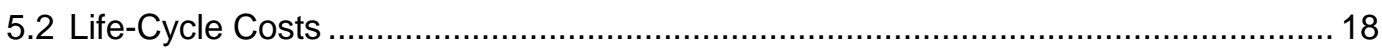

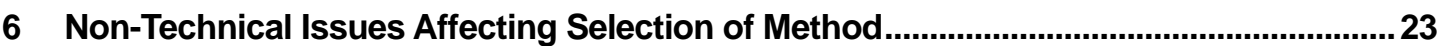

7 Summary

References

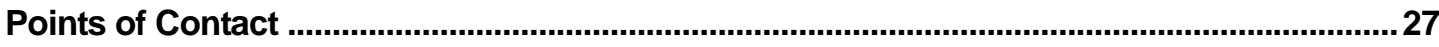

Acronyms 


\section{List of Figures and Tables}

\section{Figures}

1. Blistered encapsulant on housing unit at Fort Ord/POM............................................. 9

2. Blistered elastomeric latex on precast concrete warehouse structure .............................. 10

3. Aesthetically appealing example of paint stabilization at Fort Riley, KS......................... 19

4. Poor coating condition on Fort Ord housing unit prior to encapsulation......................... 19

\section{Tables}

1. Unit area cost* of three Army encapsulation projects.

2. Reported costs of paint stabilization and standard painting for three Army

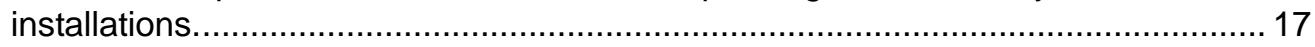

3. Reported cost of encapsulation for three Army installations. ........................................ 17

4. ASTM calculated cost ranges for interim control methods............................................ 17

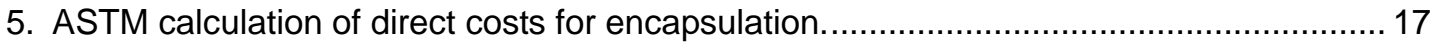

6. Installed cost ${ }^{\star}$ of encapsulation (dollars per square foot). ............................................ 18

7. Initial and periodic cost assumptions (dollars per square foot)....................................... 22

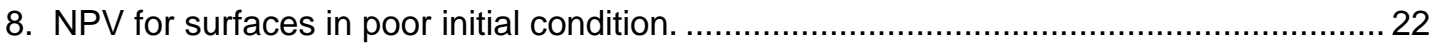

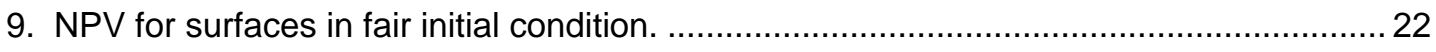

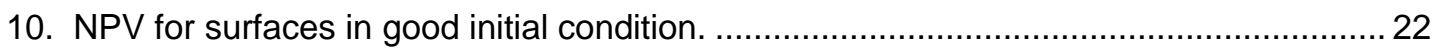




\section{Conversion Factors}

U.S. standard units of measure used in this report can be converted to SI* units as follows:

\begin{tabular}{|c|c|c|}
\hline Multiply & By & To Obtain \\
\hline acres & $4,046.873$ & square meters \\
\hline cubic feet & 0.02831685 & cubic meters \\
\hline cubic inches & 0.00001638706 & cubic meters \\
\hline degrees (angle) & 0.01745329 & radians \\
\hline degrees Fahrenheit & $(5 / 9) \times\left({ }^{\circ} \mathrm{F}-32\right)$ & degrees Celsius \\
\hline degrees Fahrenheit & $(5 / 9) \times\left({ }^{\circ} \mathrm{F}-32\right)+273.15$ & kelvins \\
\hline feet & 0.3048 & meters \\
\hline gallons (U.S. liquid) & 0.003785412 & cubic meters \\
\hline horsepower (550 ft-lb force per second) & 745.6999 & watts \\
\hline inches & 0.0254 & meters \\
\hline kips per square foot & 47.88026 & kilopascals \\
\hline kips per square inch & 6.894757 & megapascals \\
\hline miles (U.S. statute) & 1.609347 & kilometers \\
\hline pounds (force) & 4.448222 & newtons \\
\hline pounds (force) per square inch & 0.006894757 & megapascals \\
\hline pounds (mass) & 0.4535924 & kilograms \\
\hline square feet & 0.09290304 & square meters \\
\hline square miles & $2,589,998$ & square meters \\
\hline tons (force) & $8,896.443$ & newtons \\
\hline tons $(2,000$ pounds, mass $)$ & 907.1847 & kilograms \\
\hline yards & 0.9144 & meters \\
\hline
\end{tabular}

* SI: Système International d'Unités (International System of Measurement). 


\section{Preface}

This technology demonstration was conducted for Headquarters, Department of the Army under Program Element (PE) 063728A, "Environmental Technology Demonstration Project 002, "Environmental Compliance Technology"; Work Unit CF-M B101, "Cost Effective Technologies to Reduce, Characterize, Dispose, and Reuse Sources of Lead Hazards.” Bryan Nix, ACS (IM)-FDF, was the Technical Monitor.

The work was performed by the Materials and Structures Branch (CF-M) of the Facilities Division (CF) Construction Engineering Research Laboratory (CERL). The CERL Principal Investigator was Dr. Ashok Kumar. Part of this work was done by Corrosion Control Consultant and Laboratories (CCC\&L), under Contract DACA4202-P-0211. The Technical Editor was Gordon L. Cohen, Information Technology Laboratory - Champaign. Martin J. Savoie is Chief, CF-M, and L. Michael Golish is Chief, CF. The Technical Director of the Installation Operations Business Area is Gary W. Schanche (CV-T), and the Director of CERL is Dr. Alan W. Moore.

CERL is an element of the U.S. Army Engineer Research and Development Center (ERDC), U.S. Army Corps of Engineers.

At the time of preparation of this report, COL James R. Rowan, EN, was the Commander and Executive Director of ERDC, and Dr. James R. Houston was the Director. 



\section{Introduction}

\subsection{Background}

The Army owns 90,000 family housing units built before 1978 and 800,000 square feet of non-residential buildings that are likely to contain lead-based paint (LBP). Because the goal of Army housing policy is to provide safe and healthful environments for building occupants, lead hazard control is an important issue on Army installations. Two general lead hazard control strategies used by the Army are interim paint controls and abatement.

Interim controls are periodic, low-cost procedures intended to reduce lead exposure. The effectiveness of interim control procedures is periodically evaluated, and the procedures are repeated as necessary. Paint stabilization is one commonly used interim control method (HUD* 1995, Chapter 11). This form of interim control addresses not only failed paint film, but also any substrate deterioration that may have caused the paint failure. Paint stabilization specifically targets failed areas of coating, leaving intact older coatings of paint in place. The repaired substrate and failed paint areas are recoated, and the intact paint may also be topcoated as needed. The U.S. Environmental Protection Agency (EPA) estimates a four-year service life for interim paint controls (HUD 1995, Chapter 11).

Abatement is a lead hazard management strategy that permanently (20-years minimum) eliminates the hazard (HUD Guidelines, Chapter 12). Compared to interim controls, abatement provides a long-term solution to the lead paint hazard. Because abatement is unlikely to fail, very little monitoring or reevaluation of the lead hazard is required after the abatement activity. One promising form of abatement is encapsulation, which is defined as the process of making LBP inaccessible by providing a barrier between the LBP and the environment (HUD 1995, Chapter 13). The encapsulation

\footnotetext{
* HUD: U.S. Department of Housing and Urban Development.
} 
process includes repair of any deteriorated substrate and paint as well as the elimination of the underlying cause of the deterioration. The encapsulant is directly applied to the repaired surface. Encapsulants are available in the form of liquid coatings or adhesively bonded covering materials. To be a certified encapsulant, the system must be warranted for a 20 year coating life. (After 20 years maintenance will be required to reduce lead levels in dust and soil below a prescribed threshold level.) States act as the certifying agencies.

In order to select appropriate LBP maintenance options based on realistic life-cycle cost assessments, the Army must have a better understanding of the real-world durability of encapsulants versus stabilization with conventional paints applied using the same approaches. Laboratory testing has indicated that some conventional architectural paints can be expected to perform at least as well, in terms of interior durability, as encapsulants. However, documented user experience with these options for lead-based paint management is necessary in order to better judge which option works better in practice. A cost and performance record of field experience with encapsulants at several Army installations was needed to develop valid comparisons with maintenance painting using standard specification paints.

\subsection{Objective}

The objectives of this study are to compare the cost and performance of conventional paint versus encapsulant coatings for LBP-abatement purposes and to predict their service lives and life-cycle costs.

\subsection{Approach}

Seven Army installations were visited to gather cost and performance data on conventional and encapsulant coatings. Additional data from other installations were collected through telephone interviews. Coating life in terms of time to repaint was estimated based on the observed coating performance and installation practices.

Life-cycle costs for interior and exterior conventional and encapsulant coatings were calculated based on the estimated durability and costs reported by the Army installations and the coating industry. Initial paint condition, substrate material, and technological risk were accounted for in the cost analysis. 


\subsection{Regulatory Drivers}

The primary regulatory driver is Section 1017 of the Residential Lead-Based Paint Hazard Reduction Act of 1992, which is often referred to as Title X ("Title Ten") because it was enacted as Title X of the Housing and Community Development Act of 1992 (Public Law 102-550). Title $\mathrm{X}$ was implemented in part through the Code of Federal Regulations (CFR) Part 745 (29 Aug 1996), "Lead; Requirements for Lead-Based Paint Activities in Target Housing and Child-Occupied Facilities." The U.S. Department of Housing and Urban Development (HUD)" provided practical guidelines in the HUD Guidelines for the Evaluation and Control of Lead-Based Paint Hazards in Housing (Jun 1995). Army Regulation (AR 420-70, Buildings and Structures, Chapter 3, Oct 1997), established the HUD Guidelines as the standard of care for the assessment, management, and abatement of lead hazards.

Army policy states that interim controls shall be used to control lead hazards in lieu of abatement. However, when interim controls are ineffective at controlling the lead hazard, the source of the lead hazard must be abated. Abatement will only occur when interim controls are ineffective or when economically justified. Furthermore, policy calls for abatement of all existing lead-contaminated paint on surfaces to be disturbed by work when that work constitutes major repairs or whole-house revitalization projects.

Interim controls include maintaining existing lead-coated surfaces using standard painting practices and conventional materials such that lead hazards are controlled. Lead hazards are controlled as long as all of the paint layers remain intact. Standard painting practices acknowledge the presence of lead and work is performed in a leadsafe manner.

\subsection{Mode of Technology Transfer}

Technology transfer is being accomplished by: (1) a Technology Transfer Implementation Plan supervised by the U. S. Army Environmental Center (AEC); (2) dissemination of Public Works Technical Bulletin (PWTB) 420-70-2, "Installation Lead Hazard Management"; (3) participation in User Groups and Committees such as the Army Lead and Asbestos Hazard Management Team, Federal Lead-Based Paint Committee Meetings at EPA or HUD, and ASTM Committee E06.23 on Lead Hazards Associated with Buildings; (4) websites maintained by the Assistant Chief of Staff for Installation Management (ACSIM) [http://www.hqda.army.mil/acsimweb/ fd/policy/facengcur.htm], AEC [http://aec. army. mil/usaec/], and the U. S. Army Engineer Research and Development Center, Construction Engineering Research Labora- 
tory (ERDC/CERL) [http:// www.cecer.army.mil], as well as the Hands-on-Skills Training (HOST) website [http://www.hqda.army.mil/acsimweb/fd/policy/ host/index.htm]. 


\section{Overview of Encapsulant Technology}

\subsection{Regulatory Overview}

Army policy stipulates that LBP abatement will be performed when economically justified or when interim controls are deemed ineffective. Forms of abatement addressed in the HUD Guidelines include component removal, enclosure, paint removal, and encapsulation.

Enclosure as defined by HUD is the installation of a rigid, durable barrier that is mechanically attached to building components, with all edges and seams sealed with caulk or other sealant. Enclosures should have a design life of at least 20 years. Component removal, as the name implies is simply the removal and replacement of lead-coated fixtures or surfaces. Paint removalcan be accomplished either in place or by transporting contaminated materials offsite. HUD defines encapsulation as a process that makes lead-based paint inaccessible by providing a barrier between the paint and the environment. The barrier is formed using a liquid-applied coating (with or without reinforcement materials) or an adhesively bonded covering material. The primary means of attaching an encapsulant is bonding the product to the contaminated surface, either through self-adhesion or the application of a compatible adhesive.

At the time the HUD Guidelines were developed there were no approved encapsulants or standards for them. However, since the Guidelines were published in 1995, ASTM International has developed two specifications for encapsulants: E1797-00, Standard Specification for Reinforced Liquid Coating Encapsulation Products for Leaded Paint in Buildings; and E1795-00, Standard Specification for Non-Reinforced Liquid Coating Encapsulation Products for Leaded Paint in Buildings. In addition to the material specifications, ASTM has developed a user guide: E1796-97, Standard Guide for Selection and Use of Liquid Coating Encapsulation Products for Leaded Paint in Buildings. These standards are commonly included by reference in state regulations and are also referenced in DoD guide specifications, including Unified Facility Guide Specification (UFGS)13281A, Lead Hazard Control Activities. 


\subsection{Process Description}

Encapsulation is a form of abatement. Surfaces slated for abatement must first be assessed with respect to the applicability of encapsulants. If the LBP is severely deteriorated, then encapsulation is not applicable. In all other cases a test patch should be applied to assess the compatibility of the encapsulant and the existing coating. The test patch is also necessary to determine whether the underlying layers of paint can withstand the added strain that the encapsulant places on the system. In some cases the added weight or shrinkage stresses may cause some or all of the underlying paint to lose adhesion and delaminate.

Once it has been determined that encapsulants can be used successfully, the surface is cleaned to remove deteriorated paint and chalk. Specific methods such as wet scraping and sanding are employed to reduce the amount of dust formed such that worker exposures and contamination of the dwelling or environment are minimized. The integrity of the building envelope must also be assured. If repairs are necessary they should be conducted at this time.

Liquid encapsulants are applied in one or two coats. The products are typically highbuild elastomeric latex coatings. Each coat has a minimum thickness of 7 mils or greater. Some products utilize only high-quality acrylic resins. Other products use other resin emulsions as modifiers or copolymers. Encapsulants have high degrees of elongation and are very flexible. They may be spray-, brush-, or roller-applied. Larger areas are typically sprayed and then back-rolled to ensure uniform and complete coverage.

The performance and integrity of the installed encapsulant is inspected after 6 months and then annually thereafter.

\subsection{Applicability of the Technology}

As previously stated, encapsulation is a form of abatement. Abatement is performed when economically justified or when interim controls are deemed ineffective. Encapsulants can be used to overcoat both interior and exterior LBP. The encapsulation process is applicable to all substrate types including plaster, wallboard, concrete, stucco, wood, and metal. The products may be used on child-occupied facilities including residences, schools, and daycare facilities. They are also sometimes used to control lead hazards on non-child occupied facilities such as offices and other commercial-type facilities. 


\section{Technology Assessment}

\subsection{Advantages}

A chief advantage of encapsulation is its codification as an approved form of LBP abatement. Where abatement is indicated, then encapsulation can be considered an option. As a certified abatement technology, encapsulants are warranted to last a minimum of 20 years, providing much longer service life than typical interim controls.

Another advantage of encapsulation is its high film build. Two coats of paint, as opposed to one coat, have been correlated with longer service life on exterior wood (Williams 1999). Encapsulants also have low permeability, which gives the coatings good resistance to moisture intrusion.

Encapsulants are elastomeric latex coatings. They have excellent elongation properties and are very flexible. This property helps encapsulants maintain adhesion on substrates that are not dimensionally stable, such as exterior wood. Exterior wood siding and trim expands and contracts as it absorbs and desorbs water. Coatings that do not expand and contract with the substrate will eventually crack and flake from the surface. The superior flexibility of encapsulants also imparts crack bridging properties over concrete and masonry surfaces.

Abatement using encapsulants can be less disruptive than other forms of abatement. In some cases residents may not need to be relocated. Additionally, encapsulants are often less expensive than other abatement options such as paint removal or enclosure. Worker training requirements for installation of encapsulants are only moderate.

\subsection{Limitations}

On friction and impact surfaces such as doors, stairs, floors, and windows, the encapsulant may not remain intact, and therefore paint removal or component replacement is required for these items. Other surfaces that should generally be abated by means 
other than encapsulation include lead-coated hot water radiators and old calcimine coatings.

Although certified encapsulants are warranted to have a 20-year life, their long-term performance has not yet been proven in the field because they have not been available very long. It is reasonable to expect that encapsulants will be durable on interior surfaces for 20 years or more if degradation from impact, friction, and substrate moisture does not occur. However, exterior applications are much more demanding.

Coatings last longer in exterior environments if the substrate is dimensionally stable. Such is the case with concrete and stucco building surfaces. Wood, on the other hand, absorbs water and goes through fairly significant dimensional changes. These changes, coupled with the degradation of the coating itself, usually cause coatings on exterior wood to begin flaking and peeling in less than 10 years. It is highly unlikely that either conventional coatings or certified encapsulants on the market today will significantly extend the maintenance cycle on exterior wood surfaces much beyond the generally accepted maximum life of 7 to 10 years (Williams 1999).

Encapsulant coatings also have inherent weaknesses. Encapsulants are thick-film elastomeric latex coatings. Elastomerics cannot generally be formulated in dark colors because their inherent moisture sensitivity is elevated when color concentrates containing hydrophilic solvents are used to produce dark colors. Even light colors are inherently sensitive to early moisture exposure. Failures induced by early moisture exposure typically appear as large water-filled blisters (Figures 1 and 2). These types of failures are fairly common and are well documented in the literature (Bartlett 2001). They have been observed in encapsulants that were applied at the Presidio of Monterey (POM).

Another inherent feature of thick film elastomeric latex coatings is their relatively low water permeability compared with conventional architectural coatings. This property can be beneficial because the elastomeric coating will reduce water migration to the substrate, which in turn enhances long-term coating performance. However, this same property can also be problematic. Lower permeability also means that water can build up beneath the coating, typically resulting in premature failure of the coating. The phenomenon occurs when water enters the building envelope because of poor architectural details such as unsealed wall penetrations, unprotected roof parapets, poorly caulked windows, or lack of a vapor barrier. Once inside a wall, water will attempt to pass through the coating if the outdoor temperature is lower than the temperature of the wall. High-build elastomeric coatings pass water vapor at a lower rate than conventional thin film architectural coatings. When the driving force exceeds the ability of the coating to pass water vapor, liquid water will condense under the coating. If enough 
water collects under the coating, then the paint film is displaced from the substrate and a blister is formed. Irreversible film deformation may occur as well as substrate degradation. Ultimately, the coating loses adhesion and must be repaired or replaced. The failure mechanism can also be less dramatic; as moisture retained in the wood may degrade the long-term performance of the coating to cause premature peeling.

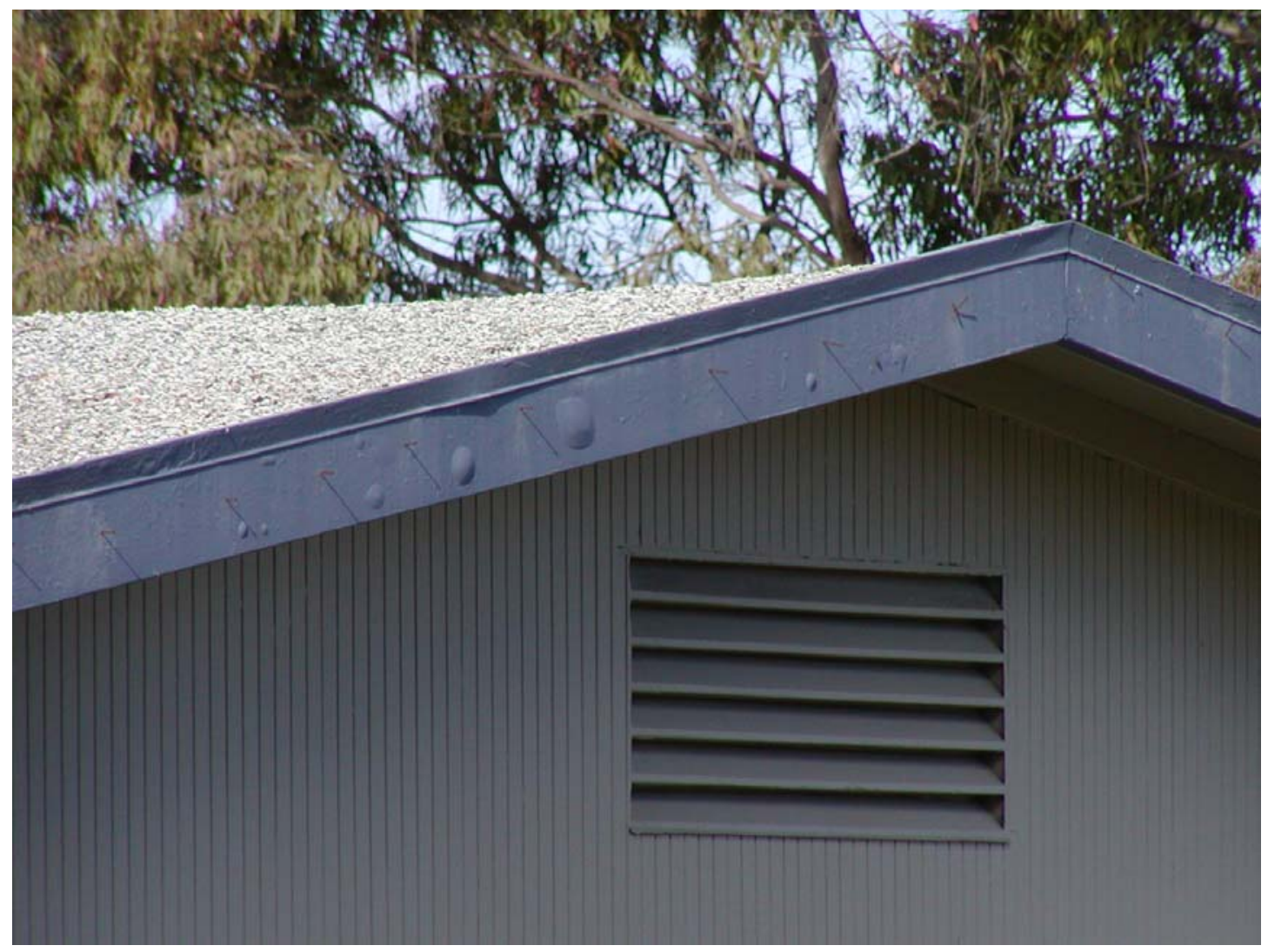

Figure 1. Blistered encapsulant on housing unit at Fort Ord/POM. 


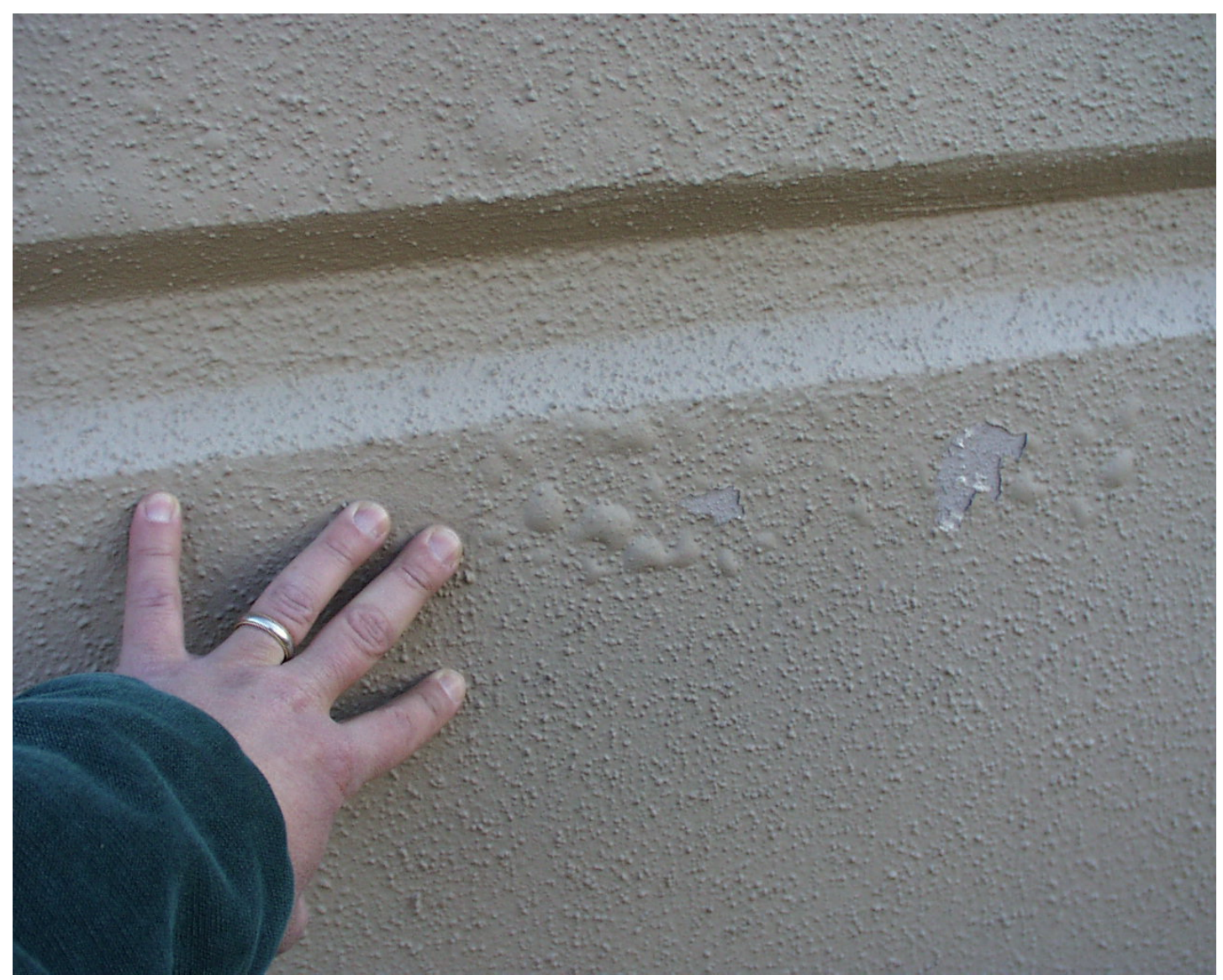

Figure 2. Blistered elastomeric latex on precast concrete warehouse structure.

Thick film stress-type failures can occur with encapsulants. The forces applied to the underlying paint layers due to cure shrinkage and the added weight of the encapsulant can cause the system to fail. These failures manifest themselves as loss of adhesion and result in delamination of the coating system from the substrate or a weak intermediate interface. The failure plane can be the substrate or between layers of old paint. These problems are similar to those encountered in the overcoating of LBP in the industrial maintenance painting industry (SSPC-TU-3). Factors typically considered here are the adhesion, thickness, type, and age of the existing coating. Patch testing is recommended for encapsulants in all cases because good performance is critical where children could be exposed to a lead hazard if the encapsulant system fails.

Proper surface preparation is a critical component of the encapsulation process. All deteriorated paint must be removed to ensure good long-term performance. Most encapsulant warranties are void if deteriorated paint is not removed before encapsulation. Some encapsulant users have attempted to use encapsulants with little or no surface preparation. In one such case the encapsulant was applied over a flaking LBP. Apparently the user mistakenly thought that encapsulants could be used to re-adhere peeling 
paint to a substrate, making removal of deteriorated paint unnecessary. However, it is generally accepted that surface preparation is the most important step in any coating operation. Duration of performance correlates strongly with the quality of surface preparation, application of paints over improperly prepared surfaces contributes to early paint failure (Williams 1999).

After an encapsulant has been successfully applied, periodic monitoring of coating integrity is necessary to ensure that the encapsulated lead remains effectively isolated from the environment.

\subsection{Cost}

The major cost components of abatement using encapsulants are patch testing, cleaning and surface preparation, encapsulant application and materials, worker training and protection, waste disposal, cleanup, and clearance testing.

Table 1 lists the unit area costs (UAC) of abatement using encapsulants at three DOD facilities.

Table 1. Unit area cost* of three Army encapsulation projects.

\begin{tabular}{|l|l|}
\hline Facility & Unit Area Cost \\
\hline Presidio of Monterey & $\$ 9.15-\$ 9.85 p e r$ square foot \\
\hline Fort Sam Houston & $\$ 9-\$ 10 p e r$ square foot \\
\hline Fort Irwin & $\$ 9-\$ 10 p e r$ square foot \\
\hline
\end{tabular}

* All costs reported by ERDC/CERL. 


\section{Performance Comparison}

\subsection{Abatement with Encapsulant Coatings}

A report prepared by Battelle* for the EPA (EPA 747-B-001, December 1998) had this to say about the effectiveness of encapsulants:

The limited data on the efficacy of encapsulation methods indicates dust-lead levels in residences abated predominantly using encapsulation or enclosure methods were typically, though not significantly, higher than those measured in residences abated primarily using removal methods (USEPA, 1996a, 1996b). Encapsulation was successful when used in combination with chemical stripping and component removal strategies (Nedellec et al., 1995). Preliminary results of the HUD Abatement Grant Program suggest that encapsulation can be effective in reducing dust-lead levels in the home and blood-lead levels of resident children (NCLSH and UC, 1998).

Abatement using encapsulant coatings is an effective means of controlling the lead hazard as assessed by its ability to lower residential lead dust levels and resident children blood-lead levels. However, abatement using encapsulants generally is not allowed for friction and impact surfaces such as floors, stairs, windows, and doors. At least one state (Massachusetts) prohibits the use of certified encapsulant on exterior surfaces.

\subsection{Interim Control with Standard Coatings}

Interim controls generally encompasses the maintenance of existing lead-contaminated surfaces in good condition, controlling lead hazards through the use of standard painting practices and materials. Peeling or chalking paint is removed by wet scraping and

\footnotetext{
* Battelle Memorial Institute, Columbus, $\mathrm{OH}$.
} 
sanding, after which the surface is repaired with conventional coatings. When the new paint begins to deteriorate the maintenance procedure is repeated. Lead hazards are controlled as long as all of the paint layers remain intact. The HUD Guidelines refer to this practice as paint film stabilization; it is also commonly known as overcoating.

The primary limitation of interim controls of this type is the frequency of repainting that is necessary to keep the lead-coated surface in good condition. Exterior applications on wood surfaces may require maintenance every 3 to 7 years to maintain the paint in good condition (Williams 1999), and this cycle is consistent with current installation practices by which exteriors are repainted on a 5 year cycle. However, it should be noted that certain maintenance painting practices can extend the repaint cycle to up to 10 years (Williams 1999) on wood substrates, and paint systems on concrete and stucco may last 20 or more years (Bartlett 2001).

Other limitations of the paint film stabilization process are similar to those encountered with encapsulants. Proper surface preparation is a critical component in paint stabilization practices. As with encapsulants, all deteriorated paint must be removed to ensure the best long-term performance, and coating service life correlates strongly with the quality of surface preparation. Also, periodic monitoring of coating integrity is necessary to ensure that lead is not available to the environment.

As with encapsulants, abatement at friction and impact surfaces such as doors, stairs, floors, and windows must be done by some other method. This is also true for leadcoated hot water radiators and old calcimine coatings.

Current painting practice at Army installations is to recoat interiors after 3 years. In practice, however, repainting may be performed more often (e.g., with each change of tenant). In accordance with this practice, interior repainting is performed more often than necessary to maintain lead-coated surfaces in good condition. Therefore, the use of interim control methods on interior surfaces does necessitate more frequent painting than specified by standard practice.

Interior coatings are subject to frequent cleaning with detergents and abrasive media. Previous research by the Army compared the scrub resistance of certified encapsulants and conventional interior latex coatings (Race 2001). Many of the conventional coatings tested had better scrub resistance than encapsulants, even when normalized for the higher film builds of the encapsulants. The likelihood of exposing LBP due to cleaning methods depends on the specific coating used. However, if carefully selected, conventional coatings should perform as well or better than encapsulants in this regard. 
The Battelle report had this to say about the effectiveness of interim paint controls:

Interim control strategies have resulted in significant declines in residential dust-lead loadings and concentrations, as well as modest declines in the bloodlead levels of resident children 9-15 months after the interventions (Weitzman et al., 1993; USEPA, 1993b, 1995b, 1997, 1998a). Preliminary results of the HUD Abatement Grant Program suggest that interim controls can be effective in reducing dust-lead levels in the home and blood-lead levels of resident children (NCLSH and UC, 1998).

Based on available data, interim control methods are qualitatively equivalent to abatement using encapsulant coatings. Both methods reduce lead dust levels and resident child blood-lead levels.

Interim controls are not considered to be a form of abatement. If abatement is required, then interim controls cannot be used.

When abatement is not required, interim control methods may be used. There is no limitation on the applicability of interim control based on substrate type, interior or exterior exposure, or type of architectural component. However, it must be recognized each different coating application will have its own specific maintenance painting cycle. 


\section{Cost Comparison}

\subsection{Installed Costs}

Seven Army installations were surveyed during Fiscal Year (FY) 2000 on painting practices and costs. All sites provided data. Two installations - Forts Riley and Campbell - reported the use of paint stabilization methods on interior and exterior surfaces to control lead hazards. The cost of maintenance painting is the same at these facilities whether lead is present or not. This reflects the fact that paint maintenance is performed often enough that the paint film is stabilized and surface preparation is kept to a minimum. Fort Drum reported that lead hazard control was not an issue because a lead survey had found only isolated instances of LBP. Those isolated items were removed and the facility uses standard Army painting practices on interior and exterior surfaces.

Fort Riley performed paint film stabilization using lead-safe techniques with appropriate resident notification, worker protection, and cleanup and clearance testing as necessary. Interior work on installations is typically accomplished as a single-coat application, and exterior paint stabilization is usually accomplished with two coats. Interior paint stabilization is generally performed every 3 years, but this is done more frequently in cases of tenant turnover. Forts Drum and Riley reported a 5 year exterior repaint cycle, and Fort Campbell reported an exterior repaint cycle of 6 years on average. The Fort Riley data probably most closely reflect the cost of interim control and paint stabilization because (1) that installation's repaint cycle is closer to the HUDrecommended 4-year cycle than Fort Campbell's and (2) its higher rate of utilization more accurately reflects expected costs.

Three facilities reported using encapsulation to control lead hazards (The Presidio of Monterey (POM), Fort Sam Houston, and Fort Irwin). The most detailed cost data were available for POM. Recent costs ( $\$ 9.15$ per square foot) are lower than when encapsulation work was begun about 5 years ago ( $\$ 9.89$ per square foot). 
No differences in extent of surface preparation were reported for facilities using standard painting practices, paint film stabilization, and encapsulation. In all cases deteriorated paint is removed before paint application.

Reported paint stabilization and standard paint costs are shown in Table 2. Reported encapsulation costs are shown in Table 3.

ASTM E2252-02, Standard Practice for the Selection of Lead Hazard Reduction Methods for Identified Risks in Residential Housing or Child Occupied Facilities, includes cost data for encapsulation and interim controls. Costs are reported in 1998 dollars and are derived from RS Means and industry figures from historic data. The ASTM interim control cost figures for interior and exterior surfaces are broken down into paint stabilization and surface preparation / dust removal unit area costs (Table 4). The encapsulation cost figures are broken down into direct material and labors costs (Table 5).

Because ASTM reported only direct costs, indirect costs for encapsulation had to be estimated. Overhead rate estimates are based on ranges recommended for development of an independent government cost estimate (IGCE) in the Defense Information Systems Agency (DISA) Acquisition Deskbook. ${ }^{*}$ DISA recommends an overhead rate on unburdened labor between $30 \%$ and $70 \%$ for work performed at the Government site. General and Administrative (G\&A) rates range from 5\% to 30\%. Contractor profit should reflect a percentage typical for the industry. Relatively high overhead (50\%) and G\&A (30\%) rates were used to extrapolate costs. Relatively high rates are indicated by environmental work entailing significant risk as well as worker protection and training requirements. Profit for contractors was assumed to be $10 \%$. The extrapolated costs are shown in Table 6.

The unit area cost of paint film stabilization is significantly lower than the cost of encapsulation. This is true for both the reported Army costs and ASTM costs. Even the most expensive interior stabilization costs less than the least expensive encapsulation. The median cost of exterior stabilization is only slightly more costly than the least expensive encapsulation.

\footnotetext{
* After this research was completed, the Under Secretary of Defense for Acquisition, Technology, and Logistics (USD [AL\&T]) authorized transitioning of the Acquisition Deskbook from a web-based server into an online library called the "Knowledge Sharing System." The so-called "Legacy Deskbook" referenced here is now hosted at http://legacydeskbook.dau.mil/. The reference list at the end of this report includes the web address for the Acquisition Deskbook at the time this portion of the research was conducted.
} 
The cost of both interior and exterior paint stabilization as reported by Army facilities is in the lower quartile of costs calculated by ASTM. The cost of encapsulation reported by Army facilities is in the upper quartile of the costs calculated by ASTM.

The cost ranges for paint stabilization and encapsulation as calculated by ASTM are quite wide. The cost of interior stabilization varies by a factor of 10 and exterior stabilization varies by a factor of almost 13 . The cost of encapsulation varies by a factor of 2.5. The wide cost ranges reflect the high cost of surface preparation. The low end of the ASTM cost ranges probably little or no surface preparation other than cleaning to remove chalk and dirt. Where paint is flaking and peeling it must be removed, leading to higher surface preparation costs. In extreme cases, where paint degradation is extensive, it becomes more cost-effective to remove all of the paint or to enclose the surface.

Table 2. Reported costs of paint stabilization and standard painting for three Army installations.

\begin{tabular}{|l|l|l|}
\hline Facility & Interior (One-Coat) & Exterior (Two-Coat) \\
\hline Fort Drum* & $\$ 0.66$ per square foot & $\$ 0.77$ per square foot \\
\hline Fort Riley & $\$ 0.27$ per square foot & $\begin{array}{l}\$ 1.52 \text { per square foot } \\
\$ 1.72 \text { per square foot complex }\end{array}$ \\
\hline Fort Campbell & $\$ 0.17$ per square foot & $\$ 0.78$ per square foot \\
\hline
\end{tabular}

* LBP not present at Fort Drum. Interior cost is based on square foot of floor space. The equivalent cost per square foot of painted surface is approximately $\$ 0.17$ per square foot.

Table 3. Reported cost of encapsulation for three Army installations.

\begin{tabular}{|l|l|}
\hline Facility & Encapsulation Cost \\
\hline Presidio of Monterey & $\$ 9.15-9.85$ per square foot \\
\hline Fort Irwin & $\$ 9.00-\$ 9.50$ per square foot \\
\hline Fort Sam Houston & $\$ 9.00-\$ 9.50$ per square foot \\
\hline Current Cost & $\$ 9.15$ per square foot \\
\hline
\end{tabular}

Table 4. ASTM calculated cost ranges for interim control methods.

\begin{tabular}{|l|l|l|}
\hline Cost Item & Interior & Exterior \\
\hline Surface Preparation/Dust Removal & $\$ 0.10-\$ 1.25$ per square foot & $\$ 0.35-\$ 2.95$ per square foot \\
\hline Paint Stabilization & $\$ 0.15-\$ 1.25$ per square foot & $\$ 0.20-\$ 4.00$ per square foot \\
\hline Total Cost* & $\$ 0.25-\$ 2.50$ per square foot & $\$ 0.55-\$ 6.95$ per square foot \\
\hline Median Cost* $^{\star}$ & $\$ 1.40$ per square foot & $\$ 3.75$ per square foot \\
\hline
\end{tabular}

*ASTM does not report total and median cost values. They are calculated here based on ASTM data.

Table 5. ASTM calculation of direct costs for encapsulation.

\begin{tabular}{|l|l|l|}
\hline Method & Direct Materials & Direct Labor \\
\hline Encapsulation & $\$ 0.55-\$ 1.20 / \mathrm{ft}$ & $\$ 1.35-\$ 3.50$ per square foot \\
\hline
\end{tabular}


Table 6. Installed cost* of encapsulation (dollars per square foot).

\begin{tabular}{|l|l|l|}
\hline Cost Item & Low & High \\
\hline Direct Labor & 1.35 & 3.50 \\
\hline Overhead @ 70\% & 0.95 & 2.45 \\
\hline Direct Materials & 0.55 & 1.20 \\
\hline Subtotal - Direct and Overhead & 2.85 & 7.15 \\
\hline General and Administrative @ 30\% & 0.85 & 2.15 \\
\hline Subtotal Direct and Indirect & 3.70 & 9.30 \\
\hline Profit @ 10\% & 0.37 & 0.93 \\
\hline Total Unit Area Cost & $\$ 4.07$ per square foot & $\$ 10.23$ per square foot \\
\hline
\end{tabular}

* Includes ASTM direct cost figures and extrapolated indirect costs based on Acquisition Deskbook methodology.

\subsection{Life-Cycle Costs}

As discussed above, surface preparation is the primary cost driver reflected in the wide range of costs reported for both paint film stabilization and encapsulation. In order to perform as intended, both encapsulant and conventional coatings must be applied to appropriately prepared surfaces. This means that all dirt, chalk, and deteriorated paint must be removed. The cost of surface preparation is the same whether a conventional paint or an encapsulant coating is used.

It is reasonable to assume that the higher end of the cost ranges for paint stabilization and encapsulation reflect similar levels of surface preparation. It is also safe to assume that these costs reflect a surface that is in relatively poor condition. Conversely, we can assume that the low end of the cost ranges is indicative of work performed on surfaces that require little surface preparation and that these surfaces can be considered to be in relatively good condition. We can also assume that the median costs of encapsulation and paint stabilization reflect some intermediate surface condition that we will call fair. Clearly it is not valid to compare the cost of stabilization on a surface in good condition to the cost of encapsulation on a surface in poor condition.

It appears that the large cost differences between paint maintenance and encapsulation at Army facilities reflects significant differences in initial substrate before treatment. Housing units examined at Fort Riley were maintained in generally good to excellent condition (Figure 3), so it is reasonable to assume that paint film stabilization required little surface preparation. Conversely the exterior encapsulation work examined at POM reflected a substrate and existing coating in generally poor condition (Figure 4). Therefore, a high degree of surface preparation was required before encapsulation. These factors are reflected in the reported costs. That is to say the cost of encapsulation 
at POM is high compared to average industry costs for encapsulation, and the cost of paint stabilization at Riley is low compared to industry average costs for that process.

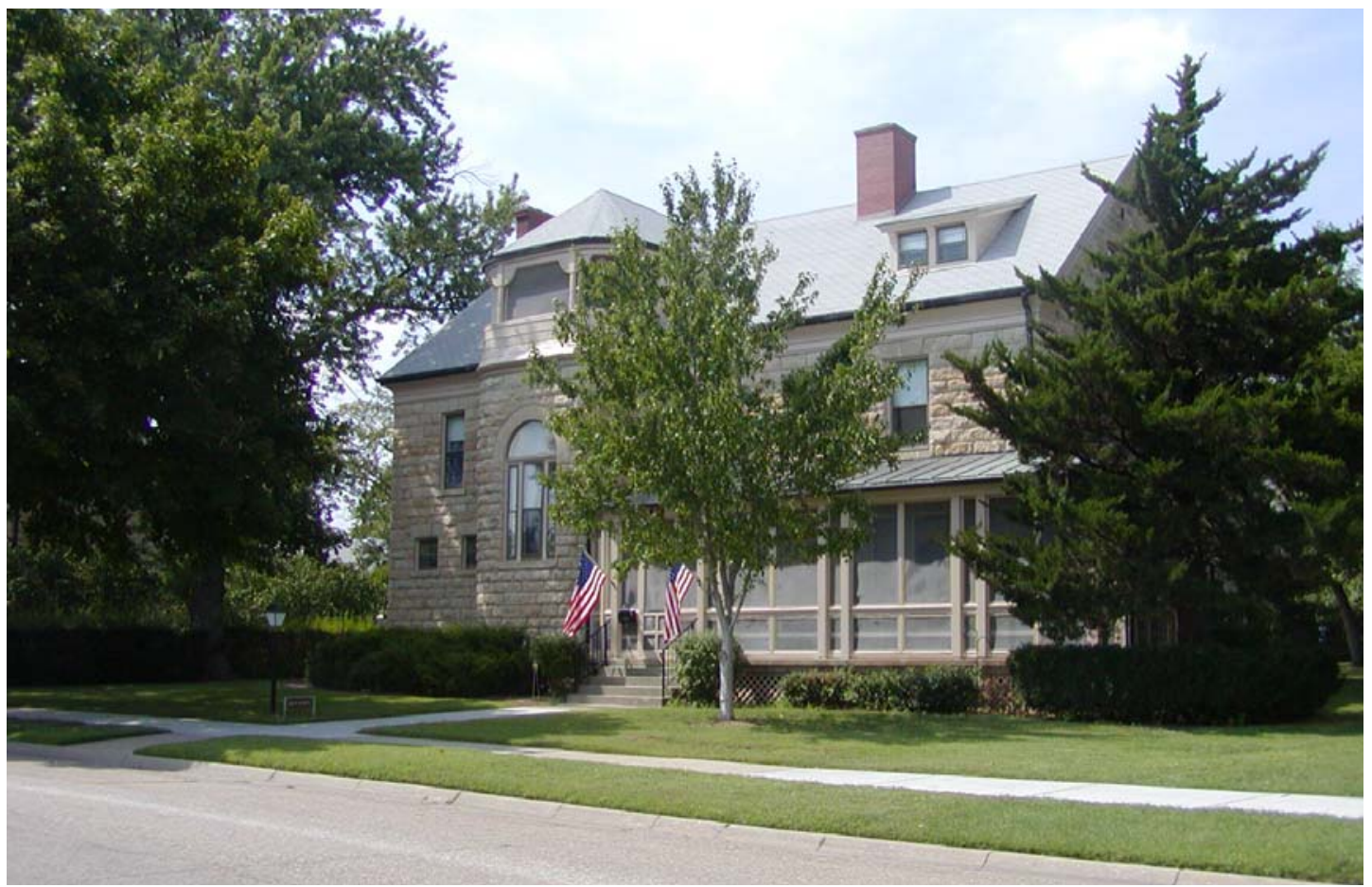

Figure 3. Aesthetically appealing example of paint stabilization at Fort Riley, KS.

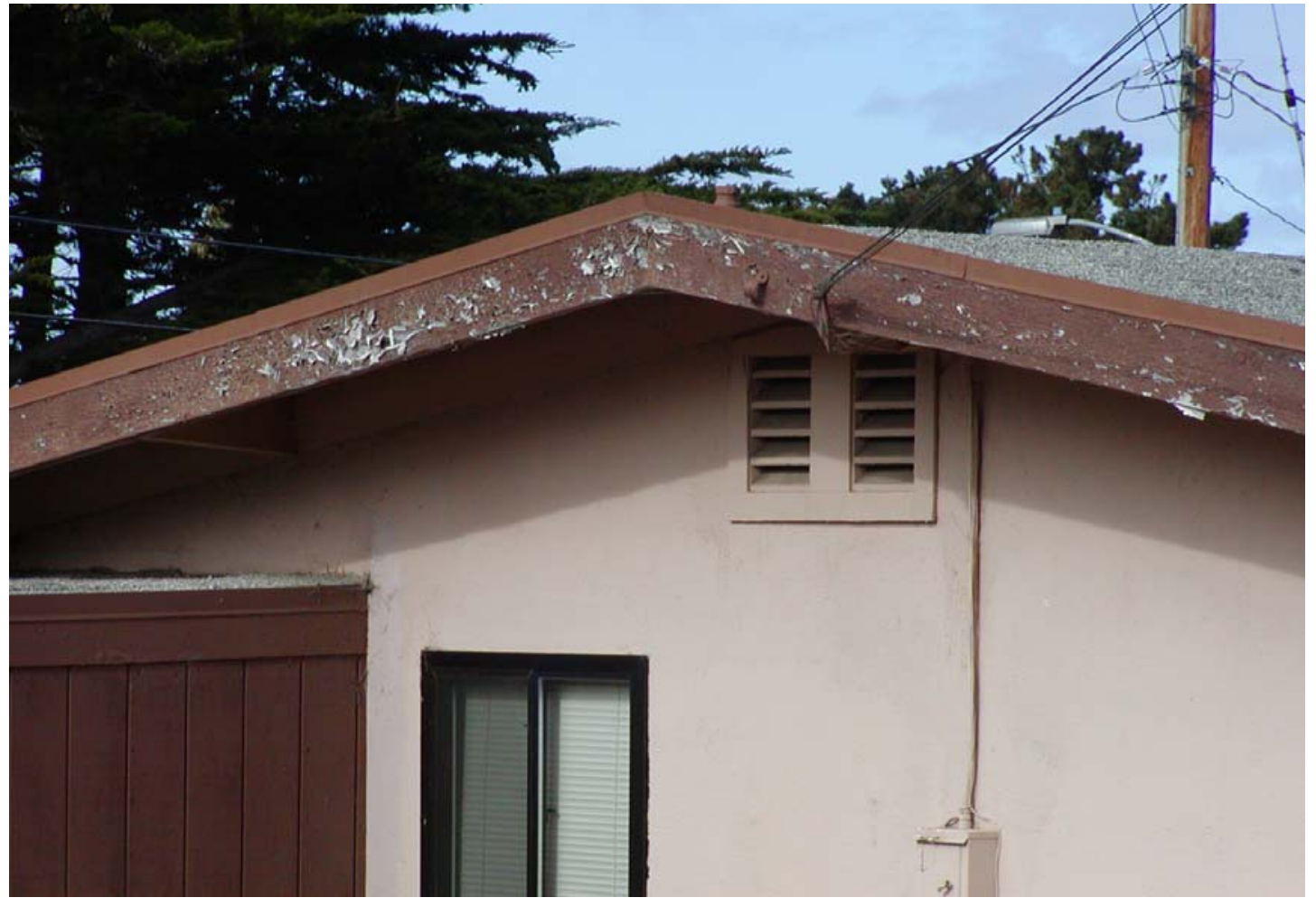

Figure 4. Poor coating condition on Fort Ord housing unit prior to encapsulation. 
Because the Army data set is somewhat limited, life-cycle costs are calculated herein using the cost factors derived from the ASTM data. Initial substrate condition is accounted for in all cases. In other words, life-cycle costs are compared only for substrates with the same initial condition. If we assume that $50 \%$ of the cost variation for each process reflects differences in surface preparation cost, then we can use the $75^{\text {th }}$ percentile cost for surfaces in poor initial condition; $50^{\text {th }}$ percentile costs are used for surfaces in fair condition initially; and $25^{\text {th }}$ percentile costs for surfaces with a good initial condition. Furthermore, it is assumed in the case of exterior paint stabilization that the level of effort needed to maintain the surface in good condition thereafter is reflected by costs near the low end of the range. Specifically it is assumed that periodic maintenance is also performed at the $25^{\text {th }}$ percentile cost. This assumption is supported by the periodic maintenance costs reported by Fort Riley wherein ongoing paint stabilization is consistently performed at low cost (17 $7^{\text {th }}$ and $1^{\text {st }}$ percentiles of the industry cost ranges for exterior and interior paint stabilization, respectively).

Life-cycle costs are computed here based on an expected building service life of 20 years. Costs are computed for poor, fair, and good initial paint conditions, which correspond with high, intermediate, and low costs. The interior and exterior maintenance cycles for paint stabilization are assumed to be 3 and 5 years, respectively, based on Army practice. Encapsulants are assumed to perform effectively for 20 years without maintenance based on their warranted performance. However, the long-term durability of encapsulants in exterior environments has not been established, and it is debatable whether their performance will meet the 20 -year mandate without at least some maintenance intervention. Therefore, two abatement scenarios are presented for comparison: one scenario in which a single preventive maintenance application is completed after 10 years and another scenario in which applications are completed after 7 and 14 years. The cost of this preventive maintenance is assumed to be equal to a low-cost application ( $25^{\text {th }}$ percentile of the industry cost range) of the encapsulant to a surface that is in relatively good condition. Initial and periodic maintenance costs for paint stabilization and encapsulation are listed in Table 7.

Life-cycle costs were also computed for interior and exterior paint film stabilization and encapsulation using actual Army costs, or $\$ 0.27$ per square foot, $\$ 1.62$ per square foot, and $\$ 9.15$ per square foot, respectively. Life-cycle costs were also calculated for exterior paint film stabilization on dimensionally stable substrates (i.e., concrete, brick, and stucco). Paint stabilization was assumed to last 10 years before another treatment is required. This assumption is conservative because conventional two-coat latex systems are known to provide 20 or more years of service on concrete, even in severe tropical climates (Bartlett 2001). 
Net present values (NPV) were calculated using ECONPACK* version 2.1.2. Values were calculated assuming a 20-year economic life. OMB Circular A-94, Guidelines and Discount Rates for Benefit-Cost Analysis of Federal Programs, instructs that the discount rate for Government investment analysis be tied to the rate at which the Federal government is willing to borrow money. The discount rate used is the nominal treasury rate whose maturity is most nearly equal to the period of analysis. Costs were measured in current dollars and a nominal discount rate (which implicitly includes inflation) was used to calculate the NPV. A discount rate of 5.375\%, based on the yield of 30-year U.S. treasury notes as of 16 December 2002, was used.

NPVs for paint stabilization and encapsulation for surfaces with poor, fair, and good initial conditions are summarized in Tables 8, 9, and 10, respectively. Lower life-cycle cost options have lower NPV.

Several general conclusions can be drawn from the life-cycle cost analyses.

- Irrespective of initial paint condition, it is always more cost-effective to control lead hazards on interior surfaces and dimensionally stable exterior substrates using paint film stabilization instead of encapsulation.

- Army costs for interior and exterior paint stabilization of surfaces that are continuously maintained in good condition is cost-effective, so switching to encapsulation is not warranted.

- Irrespective of initial paint condition, encapsulation of exterior wood surfaces (i.e., substrates that are not dimensionally stable) is slightly more cost-effective than paint stabilization.

- Army costs for exterior encapsulation on wood with a poor initial condition is nearly identical to the cost of paint stabilization.

- When the risk of lead hazard failure is taken into account, encapsulation is always less cost-effective than paint stabilization.

\footnotetext{
* ECONPACK Economic Analysis software programmed for the U.S. Army Engineer Support Center, Huntsville, AL, by Computer Sciences Corportation, El Segundo, CA 90245.
} 
Table 7. Initial and periodic cost assumptions (dollars per square foot).

\begin{tabular}{|l|l|l|l|}
\hline \multirow{2}{*}{\multicolumn{1}{|c|}{ Process }} & \multicolumn{2}{c|}{ Initial Paint Condition } \\
\cline { 2 - 4 } & \multicolumn{1}{|c|}{ Poor } & \multicolumn{1}{c|}{ Fair } & \multicolumn{1}{c|}{ Good } \\
\hline Initial encapsulation & $8.68\left(75^{\text {th }}\right.$ percentile $)$ & $7.15\left(50^{\text {th }}\right.$ percentile $)$ & $5.61\left(25^{\text {th }}\right.$ percentile $)$ \\
\hline Periodic encapsulation & $\mathrm{NA}$ & $\mathrm{NA}$ & $3.27\left(25^{\text {th }}\right.$ percentile $)$ \\
\hline $\begin{array}{l}\text { Initial exterior paint } \\
\text { stabilization }\end{array}$ & $5.35\left(75^{\text {th }}\right.$ percentile $)$ & $3.75\left(50^{\text {th }}\right.$ percentile $)$ & $2.15^{\text {th }}$ percentile $)$ \\
\hline $\begin{array}{l}\text { Periodic exterior paint } \\
\text { stabilization }\end{array}$ & $\mathrm{NA}$ & $\mathrm{NA}$ & $1.83\left(25^{\text {th }}\right.$ percentile $)$ \\
\hline $\begin{array}{l}\text { Initial interior paint } \\
\text { stabilization }\end{array}$ & $1.94\left(75^{\text {th }}\right.$ percentile $)$ & $1.40\left(50^{\text {th }}\right.$ percentile $)$ & $0.81\left(25^{\text {th }}\right.$ percentile $)$ \\
\hline $\begin{array}{l}\text { Periodic interior paint } \\
\text { stabilization }\end{array}$ & NA & NA & $0.81\left(25^{\text {th }}\right.$ percentile $)$ \\
\hline
\end{tabular}

Table 8. NPV for surfaces in poor initial condition.

\begin{tabular}{|l|l|}
\hline Lead Hazard Control Method & NPV (\$per square foot) \\
\hline Interior paint stabilization & 4.72 \\
\hline Paint stabilization on exterior concrete/masonry & 6.45 \\
\hline Encapsulation interior/exterior & 8.46 \\
\hline Army encapsulation & 8.91 \\
\hline Paint stabilization exterior wood & 9.02 \\
\hline Encapsulation exterior - risk-based (one repair) & 11.69 \\
\hline Encapsulation exterior - risk-based (two repairs) & 14.87 \\
\hline
\end{tabular}

Table 9. NPV for surfaces in fair initial condition.

\begin{tabular}{|l|l|}
\hline Lead Hazard Control Method & NPV (\$per square foot) \\
\hline Interior paint stabilization & 4.19 \\
\hline Paint stabilization on exterior concrete/masonry & 4.89 \\
\hline Encapsulation interior/exterior & 6.96 \\
\hline Paint stabilization exterior wood & 7.46 \\
\hline Encapsulation exterior - risk-based (one repair) & 10.20 \\
\hline Encapsulation exterior - risk-based (two repairs) & 13.38 \\
\hline
\end{tabular}

Table 10. NPV for surfaces in good initial condition.

\begin{tabular}{|l|l|}
\hline Lead Hazard Control Method & NPV (\$per square foot) \\
\hline Army interior paint stabilization & 1.21 \\
\hline Paint stabilization on exterior concrete/masonry & 3.34 \\
\hline Interior paint stabilization & 3.62 \\
\hline Army exterior paint stabilization & 4.45 \\
\hline Encapsulation interior/exterior & 5.47 \\
\hline Paint stabilization exterior wood & 5.90 \\
\hline Encapsulation exterior - risk-based (one repair) & 8.70 \\
\hline Encapsulation exterior - risk-based (two repairs) & 11.87 \\
\hline
\end{tabular}




\section{Non-Technical Issues Affecting Selection of Method}

This analysis is limited to a life-cycle cost comparison of paint film stabilization with encapsulation. However, it is appropriate to note that abatement options other than encapsulation may be more appropriate forms of lead control in certain cases, or may also be more cost-effective than either paint stabilization or encapsulation.

Fund allocation also may play a role in the type of lead hazard control selected by the end user. In some cases where encapsulation is identified as more cost effective, the higher installed cost may be prohibitive to the end user. In some cases funds may be allocated specifically for abatement, in which case paint stabilization could not be performed because it is not a type of abatement.

Local regulations or policy also may affect which method of lead control is selected. Encapsulation is not universally accepted as a form of lead abatement. Australia, for example, does not recognize encapsulation as a form of abatement, but groups encapsulants conventional paints and encapsulants as appropriate for stabilizing lead-coated surfaces for purposes of paint film stabilization. In another example, the Commonwealth of Massachusetts prohibits the use of encapsulants on exterior surfaces. 


\section{Summary}

This Technology Assessment study compared the cost and performance of lead paint hazard control using two competing approaches: interim paint controls and lead paint abatement. Specifically, the cost and performance of the paint film stabilization method was compared with that of liquid encapsulant abatement technology. The objective of the study was to calculate and compare the service lives and life-cycle costs of the competing lead hazard control methods.

Cost and performance data on conventional and encapsulant coatings were gathered during site visits to seven Army installations and from additional industry data sources. Life-cycle costs for interior and exterior conventional paints and encapsulant coatings were calculated based on the estimated durability and costs reported by the Army installations and the industry sources. Initial paint condition, substrate material, and risk were accounted for in the cost analysis.

It was found that irrespective of initial paint condition, it is always more cost effective to control lead hazards on interior surfaces and exterior concrete/masonry surfaces using paint film stabilization methods. When the risk of lead hazard control failure is taken into account, paint stabilization is always more cost effective than encapsulation on exterior wood siding. If encapsulants in fact do provide a 20 -year service life consistent with their warranty, then they would offer a slight life-cycle cost advantage over paint stabilization. No long-term field data are available for encapsulant coatings, however, because the technology has not yet been on the market long enough to conduct 20 -year tests. At the same time, documented Army cost and performance data for interior and exterior paint stabilization on surfaces continuously maintained in good condition demonstrate that paint stabilization is very inexpensive. Therefore, switching to encapsulation cannot be justified in terms of cost and performance, especially when the risk of lead hazard control failure is considered.

Army policy states that interim controls shall be used to control lead hazards, and that abatement technologies will be used only when interim controls are ineffective or when abatement is economically justified. Based on the findings of this study, there appears to be no significant economic justification for using liquid encapsulant coatings in lieu of conventional paint stabilization methods. 


\section{References}

Army Regulation [AR] 420-70, Facilities Engineering, Buildings and Structures (Headquarters, Department of the Army [HQDA], Washington, DC, 10 Oct 1997).

American Society for Testing and Materials (ASTM) E2252-02, Standard Practice for the Selection of Lead Hazard Reduction Methods for Identified Risks in Residential Housing or Child Occupied Facilities.

Acquisition Deskbook - Independent Government Cost Estimates (Defense Information Systems Agency, 1998), currently available online only at http://legacydeskbook.dau.mil/; previously hosted at http://disa.dtic.mil/D4/igce98.html.

ASTM E1797-00, Standard Specification for Reinforced Liquid Coating Encapsulation Products for Leaded Paint in Buildings.

ASTM E1795-00, Standard Specification for Non-Reinforced Liquid Coating Encapsulation Products for Leaded Paint in Buildings.

ASTM E1796-97, Standard Guide for Selection and Use of Liquid Coating Encapsulation Products for Leaded Paint in Buildings.

Bartlett, D. J., "High-Build Latex Coatings for Protecting and Decorating Concrete and Related Building Surfaces,” Journal of Protective Coating and Linings, September 2001.

Code of Federal Regulations (CFR) Part 745 (29 Aug 96) Lead; Requirements for Lead-Based Paint Activities in Target Housing and Child-Occupied Facilities.

Environmental Protection Agency (EPA) 747-B-98-001, Review of Studies Addressing Lead Abatement Effectiveness: Updated Edition, Prepared by Battelle for U.S. EPA, December 1998.

Environmental Security Technology Certification Program (ESTCP) Cost and Performance Report, Technology Demonstration of Self-Healing Coatings for In-Place Management of Lead-Based Paint Hazards (in publication).

Office of Management and Budget (OMB) Circular A-94, Guidelines and Discount Rates for BenefitCost Analysis of Federal Programs.

Race, T. D., Durability Assessment of Encapsulants and Standard Specification Paints, contract report prepared by Corrosion Control Consultants and Labs for U.S. Army ERDC/CERL, May 2001.

SSPC-TU-3, Overcoating, SSPC Painting Manual, Volume 2, Systems and Specifications, $8^{\text {th }}$ Ed., May 1, 1997. 
Unified Facilities Guidance Specifications, Section 13281A, Lead Hazard Control Activities, April 2000.

U. S. Department of Housing and Urban Development, Guidelines for the Evaluation and Control of Lead-Based Paint Hazards in Housing, June 1995.

Williams, R. S., Wood Handbook-Wood as an Engineering Material, Chapter 15 Wood Finishing, Forest Products Laboratory, U.S. Department of Agriculture, Forest Service, FPL-GTR-113, 1999. 


\section{Points of Contact}

\begin{tabular}{|c|c|c|c|}
\hline Name & Organization & Phone/Fax/E-mail & Project Role \\
\hline Dr. Ashok Kumar & $\begin{array}{l}\text { ERDC/CERL } \\
\text { P. O. Box } 9005 \\
\text { Champaign, IL 61826-9005 }\end{array}$ & $\begin{array}{l}\text { Tel: 217-373-7235 } \\
\text { Fax: 217-373-7222 } \\
\text { a-kumar@cecer.army.mil } \\
\end{array}$ & Principal Investigator \\
\hline Dr. L. D. Stephenson & $\begin{array}{l}\text { ERDC/CERL } \\
\text { P. O. Box } 9005 \\
\text { Champaign, IL 61826-9005 }\end{array}$ & $\begin{array}{l}\text { Tel: 217-373-6758 } \\
\text { Fax: 217-373-7222 } \\
\text { l-stephenson@cecer.army.mil } \\
\end{array}$ & $\begin{array}{l}\text { Assistant Investigator } \\
\text { /Contract Monitor }\end{array}$ \\
\hline Tim Race & $\begin{array}{l}\text { Corrosion Control Consultants and Labs } \\
135 \text { Addison Ave., Suite } 108 \\
\text { Elmhurst, IL } 60126\end{array}$ & $\begin{array}{l}\text { Tel: 630-834-3811 } \\
\text { Fax: 630-834-3812 } \\
\text { trace@ccclabs.com } \\
\end{array}$ & Principal Consultant \\
\hline Anthony Barcinas & $\begin{array}{l}\text { Defense Language Institute } \\
\text { Directorate of Public Works } \\
\text { ATTN: ATZP-DPW } \\
\text { Monterey, CA } 93944 \\
\end{array}$ & $\begin{array}{l}\text { Tel: 831-242-7779 } \\
\text { Fax: 831-242-5569 } \\
\text { barcinast@pom-emh1.army.mil }\end{array}$ & Site Contact \\
\hline John Mendez & Fort Sam Houston & $\begin{array}{l}\text { Tel: 210-221-5196 } \\
\text { jonny.mendez@cen.amedd.army.mil }\end{array}$ & Site Contact \\
\hline Muhammad Bari & $\begin{array}{l}\text { AFZJ-PW-EV, Bldg. } 385 \\
\text { Fort Irwin, CA 92310-5097 }\end{array}$ & $\begin{array}{l}\text { Tel: 760-380-3410 } \\
\text { Fax: 760-380-5293 } \\
\text { muhammadb@irwin.army.mil }\end{array}$ & Site Contact \\
\hline Jerry Knickerbacher & $\begin{array}{l}\text { AFZB-PW-E-C } \\
86513^{\text {th }} \text { Street } \\
\text { Fort Campbell, KY 42223-5130 }\end{array}$ & $\begin{array}{l}\text { Tel: } 270-798-9597 \\
\text { Fax: } 270-956-2484 \\
\text { knicker- } \\
\text { boj@campbell.army.mil }\end{array}$ & Site Contact \\
\hline James Gray & 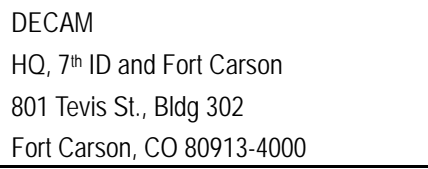 & $\begin{array}{l}\text { Tel: 719-526-3127 } \\
\text { Fax: 719-526-1705 } \\
\text { gravi@Carson-exch1.army.mil }\end{array}$ & Site Contact \\
\hline $\begin{array}{l}\text { Tom Ferguson } \\
\text { Jim Haynes }\end{array}$ & $\begin{array}{l}\text { Fort Drum Operations and Maintenance } \\
\text { Division Public Works (T. Ferguson) } \\
\text { 1st Street, Bldg. T-4004 } \\
\text { Fort Drum, NY 13602-5097 }\end{array}$ & $\begin{array}{l}\text { Tel: 315-772-4947 } \\
\text { Fax: 315-772-2505 } \\
\text { fergusont@drum-emh1.army.mil }\end{array}$ & Site Contact \\
\hline $\begin{array}{l}\text { Pam Neuman } \\
\text { Audry Chavis }\end{array}$ & $\begin{array}{l}\text { Facilities Section } \\
\text { Fort Riley, KS } 66442\end{array}$ & $\begin{array}{l}\text { Tel: 785-239-0647 } \\
\text { Tel: 785-239-2498 } \\
\text { chavisa@riley.army.mil } \\
\text { neumanp@riley.army.mil } \\
\end{array}$ & Site Contact \\
\hline George Thomas & $\begin{array}{l}\text { Confidential Compliance Consultants } \\
59 \text { W. Mendocino St. } \\
\text { Altadena, CA } 91001\end{array}$ & $\begin{array}{l}\text { Tel: 626-798-9566 } \\
\text { Fax: 626-798-9555 }\end{array}$ & Subject Area Expert \\
\hline Fred Eberle & $\begin{array}{l}\text { Dewberry and Davis } \\
8401 \text { Arlington Blvd. } \\
\text { Fairfax, VA 22031-4666 }\end{array}$ & $\begin{array}{l}\text { Tel: 703-849-0375 } \\
\text { Fax: 703-849-0118 }\end{array}$ & Subject Area Expert \\
\hline Susan Drozdz & $\begin{array}{l}\text { ERDC/CERL } \\
\text { P. O. Box } 9005 \\
\text { Champaign, IL 61826-9005 }\end{array}$ & $\begin{array}{l}\text { Tel: 217-373-6767 } \\
\text { Fax: 217-373-7222 } \\
\text { s-drozdz@cecer.army.mil }\end{array}$ & Subject Area Expert \\
\hline
\end{tabular}




\section{Acronyms}

\begin{tabular}{ll} 
AR & Army Regulation \\
ASTM & American Society for Testing and Materials \\
CFR & Code of Federal Regulations \\
DISA & Defense Information Systems Agency \\
DoD & Department of Defense \\
EPA & U.S. Environmental Protection Agency \\
FORA & Fort Ord Reuse Authority \\
FPL & Forest Products Laboratory \\
FY & Fiscal Year \\
G\&A & General and Administrative \\
HUD & U.S. Department of Housing and Urban Development \\
LBP & lead-based paint \\
NCLSH & National Center for Lead-Safe Housing \\
NPV & net present value \\
OMB & Office of Management and Budget \\
POM & Presidio of Monterey \\
UAC & unit area cost \\
UFGS & Unified Facilities Guide Specification \\
\hline
\end{tabular}




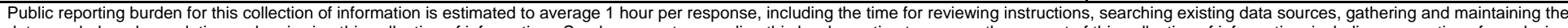

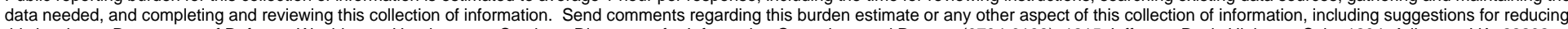

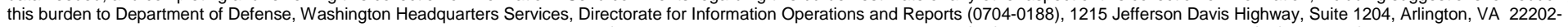

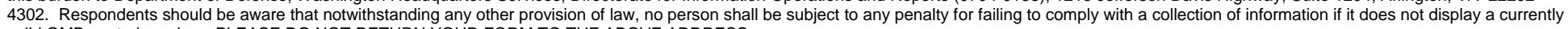
valid OMB control number. PLEASE DO NOT RETURN YOUR FORM TO THE ABOVE ADDRESS.
1. REPORT DATE (DD-MM-YYYY)
$12-2003$

4. TITLE AND SUBTITLE

Technology Assessment of Liquid Encapsulants for Lead-Based Paint Abatement
3. DATES COVERED (From - To)

5a. CONTRACT NUMBER

5b. GRANT NUMBER

5c. PROGRAM ELEMENT NUMBER

063728A

5d. PROJECT NUMBER

Timothy D. Race and Ashok Kumar

\section{5f. WORK UNIT NUMBER}

CF-M

7. PERFORMING ORGANIZATION NAME(S) AND ADDRESS(ES)

U.S. Army Engineer Research and Development Center (ERDC)

Construction Engineering Research Laboratory (CERL)

8. PERFORMING ORGANIZATION REPORT

NUMBER

ERDC/CERL TR-03-31

PO Box 9005

Champaign, IL 61826-9005

\section{SPONSORING I MONITORING AGENCY NAME(S) AND ADDRESS(ES)}

Headquarters, Department of the Army

10. SPONSOR/MONITOR'S ACRONYM(S)

Attn: DAIM-FDF

600 Army Pentagon

Washington, DC 2031-0600

11. SPONSOR/MONITOR'S REPORT NUMBER(S)

\section{DISTRIBUTION I AVAILABILITY STATEMENT}

Approved for public release; distribution is unlimited.

\section{SUPPLEMENTARY NOTES}

Copies are available from the National Technical Information Service, 5285 Port Royal Road, Springfield, VA 22161.

\section{ABSTRACT}

An evaluation of lead-based paint maintenance options was conducted based on realistic life-cycle cost assessments of the relative durabilities of encapsulants and conventional paint when employed using the same approaches. A record of field experiences of several military installations with cost and performance of encapsulants versus maintenance painting with standard specification paints was developed.

It was found that, irrespective of initial paint condition, it is generally more cost-effective to control lead hazards by paint stabilization than by encapsulation on interior and dimension-ally stable exterior substrates. Only in the case of exterior wood substrates were encapsulants found to be slightly more cost-effective than paint stabilization. However, this small cost advantage does not account for the potential risk of lead hazard control failure, a risk that is not yet well quantified for encapsulants since they are still relatively new to the market. Proper surface preparation is the primary cost driver for both encapsulation and paint stabilization, so for either technology to perform as intended, the surfaces to which they are applied must be properly prepared and all substrate damage must be repaired.

\section{SUBJECT TERMS}

maintenance and repair, lead-based paint, life cycle costs, hazardous waste, coatings

\section{SECURITY CLASSIFICATION OF:}

\section{a. REPORT} Unclassified

\section{b. ABSTRACT} Unclassified c. THIS PAGE Unclassified

\section{LIMITATION} OF ABSTRACT

SAR
18. NUMBER OF PAGES

40 19a. NAME OF RESPONSIBLE PERSON Timothy D. Race

19b. TELEPHONE NUMBER (include area code)

217/352-6511 